\title{
Lepidochitona pseudoliozonis, una nueva especie de quitón (Polyplacophora: Ischnochitonidae) del norte del Caribe
}

\author{
Cedar I. García-Ríos \\ Departamento de Biología, Universidad de Puerto Rico en Humacao, 100 Carr 908, Estación Postal CUH, Humacao, \\ Puerto Rico 00791; cedar.uprh@gmail.com
}

Recibido 24-VI-2014. Corregido 30-IX-2014. Aceptado 31-X-2014.

\begin{abstract}
Lepidochitona pseudoliozonis, a new species of chiton (Polyplacophora: Ischnochitonidae) from the North of the Caribbean. The genus Lepidochitona (Gray 1821) contains relatively small chitons with a distinctive girdle, dorsally clothed with non-overlapping calcareous corpuscles. In the Caribbean, it is represented by four species: L. liozonis (Dall, \& Simpson, 1901), L. rosea Kaas, 1972, L. rufoi García-Ríos, 2010 and L. bullocki García-Ríos, 2011. A rutinary morphological inspection of 10 specimens of a Lepidochitona species from the Florida Keys was concordant with L. liozonis (the only species of the genus informed for Florida). They did not show many morphological differences that could justify its separation from the specimens from Puerto Rico (the type locality). However, the comparison of sequences of the mitochondrial gene coding for cytochrome oxidase I (COI) of L. liozonis from Puerto Rico and the Florida specimens showed a divergence of $14 \%$. This divergence is incompatible with a reproductively connected species. In addition to their genetic differences, the new species differs from L. liozonis in having bigger size, longer marginal spicules and a postmucronal slope very concave. Rev. Biol. Trop. 63 (2): 369-384. Epub 2015 June 01.
\end{abstract}

Key words: Mollusca, chiton, Lepidochitona, Caribbean, sibling species.

El género Lepidochitona (Gray, 1821) agrupa a quitones relativamente pequeños que se pueden encontrar bajo rocas a profundidades menores de dos metros. El género está representado en el Caribe por cuatro especies: L. liozonis (Dall, \& Simpson, 1901), L. rosea Kaas, 1972, L. rufoi García-Ríos, 2010 y L. bullocki García-Ríos, 2011. La inspección de una muestra de diez ejemplares de los cayos de la Florida permite distinguir ejemplares de lepidoquitones que podrían clasificarse como L. liozonis (la única especie del género informada para la Florida) por no presentar diferencias morfológicas que justifiquen su separación de los de Puerto Rico (localidad del tipo). Sin embargo, la comparación de secuencias del gen mitocondrial que codifica para el citocromo oxidasa I (COI) de los ejemplares de la Florida con ejemplares de L. liozonis de Puerto Rico evidencia una divergencia incompatible con especies reproductivamente conectadas.

Algunos de nuestros ejemplares de lepidoquitones de la Florida son similares a un ejemplar que aparece fotografiado en 1940, en The Nautilus 53(3) y se identifica como Lepidochitona tropica Pilsbry. De ese ejemplar solo se indica que mide $13.8 \mathrm{~mm}$ de largo y que fue recolectado en Bonefish Key, Florida. Esta especie, sin embargo, no fue descrita, por lo que se le considera un nomen nudum.

Kaas (1972) reconoce la existencia de la fotografía y examina cuatro ejemplares secos de la misma localidad del ejemplar de Pilsbry (Bonefish Key, Florida; actualmente Fat Deer Key). Reconoce que los ejemplares son más grandes que los de la especie Lepidochitona liozonis, pero advierte que, excepto que son más grandes, no puede establecer ninguna 
diferencia de valor taxonómico para justificar la separación de los ejemplares examinados de la especie L. liozonis. Concluye que L. tropica se puede considerar una variedad local de $L$. liozonis y presenta su descripción.

De acuerdo al Código Internacional de Nomenclatura Zoológica (International Code of Zoological Nomenclature, 1999), para publicaciones posteriores al 1960, el uso del término "variedad" representa una categoría infrasubespecífica (Artículo 45.6.3). El nombre de la variedad "tropica" no puede volverse disponible por acción posterior, como lo sería una elevación de categoría (Artículo 45.5.1).

El objetivo de este estudio fue describir una nueva especie de lepidoquitón. Esta nueva especie es hermana de L. liozonis y probablemente incluye la "variedad robusta" de la Florida que tanto Pilsbry (1940) como Kaas (1972) reseñaron en su momento. Para establecer la distancia genética entre las especies utilizamos secuencias del gen mitocondrial COI.

\section{MATERIALES Y MÉTODOS}

Recolección y análisis morfológico de los ejemplares: Diez ejemplares de L. pseudoliozonis sp. nov. fueron recolectados en el sublitoral somero $(<2 \mathrm{~m})$, bajo rocas y escombros en el sur de Pigeon Key, la Florida, en los alrededores de $24^{\circ} 42^{\prime} 10.81^{\prime \prime} \mathrm{N}-81^{\circ} 9^{\prime} 18.16^{\prime \prime}$ W. La ubicación geográfica de los ejemplares recolectados se determinó mediante la lectura de la latitud y longitud de un punto cercano al lugar de recolección, usando un GPS. Los quitones fueron relajados y aplanados para su preservación usando alcohol etílico al 95\%.

Los organismos preservados fueron examinados, medidos y fotografiados utilizando un microscopio de disección Nikon SMZ1500 con un micrómetro en el ocular. Los elementos del cinturón tienen una parte embebida en una base de quitina transparente, que es opaca para el microscopio electrónico de barrido (MEB), pero visible en el microscopio de luz. Para determinar las dimensiones y colores de esos elementos se utilizó un microscopio compuesto (Olympus BH-2) con gradilla calibrada para medir. Todas las medidas de las estructuras expuestas se corroboraron con fotografías del MEB.

Dos ejemplares fueron totalmente desarticulados para el examen de la rádula, de las valvas y del cinturón, usando un MEB. Los ejemplares se sumergieron en una solución de $\mathrm{KOH} 2 \mathrm{~N}$, para disolver el tejido blando. Una vez que las estructuras estuvieron limpias se enjuagaron con agua destilada y se almacenaron en etanol al 95\%.

Las estructuras seleccionadas para preparar las microfotografías, utilizando el MEB, se secaron al aire y se fijaron en bases de aluminio usando un adhesivo de carbón. Estos ejemplares se cubrieron con una película de oro usando un evaporador. La determinación de la densidad de los estetos se realizó utilizando fotografías de la superficie del tegumento con magnificaciones de 400X. Sobre las fotos se dibujaron cuadrantes de $250 \times 100 \mu \mathrm{m}$ y se realizó el conteo de los poros.

Obtención de datos moleculares: $\mathrm{La}$ extracción del ADN se realizó utilizando el Kit de QIAGEN DNeasy Blood \& Tissue Kit. La muestra se tomó de tres ejemplares, usando el pie completo (aproximadamente 10mg). El ADN extraído fue diluido en agua estéril (200 $\mu \mathrm{L})$ y se almacenó a $4^{\circ} \mathrm{C}$.

La reacción en cadena de polimerasa (PCR) se realizó con el ADN extraído y los iniciadores universales del COI: LCOI $1490 \mathrm{y}$ HCOI 2198 (Folmer, Black, Hoeh, Lutz, \& Vrijenhoek, 1994). Las reacciones de PCR $(25 \mu \mathrm{L})$ incluyen $0.5 \mu \mathrm{L}$ del ADN del ejemplar, $0.5 \mu \mathrm{L}$ de cada iniciador $(5 \mathrm{pmol} / \mu \mathrm{L}), 2 \mu \mathrm{L}$ de mezcla de dNTP $(2.5 \mathrm{mM}$ cada uno), $5 \mu \mathrm{L}$ amortiguador de PCR (5X) (Promega), $2.5 \mu \mathrm{L}$ de $2.5 \mathrm{mM}$ $\mathrm{MgCl} 2$ (Promega) y $0.25 \mu \mathrm{L}$ de Taq ADN polimerasa $(5 \mathrm{U} / \mu \mathrm{L})$ (Promega). Las reacciones de PCR se realizaron usando un termociclador de Applied Biosystems modelo 2720. Las condiciones térmicas del ciclo iniciaban con desnaturalización de $5 \mathrm{~min}$ a $95^{\circ} \mathrm{C}$, seguido de 35 ciclos que incluyen desnaturalización a $95^{\circ} \mathrm{C}$ durante $30 \mathrm{~s}$, alineamiento a $45^{\circ} \mathrm{C}$ durante $30 \mathrm{~s}$ y la extensión a $72^{\circ} \mathrm{C}$ durante 1 minuto, 
con un paso de extensión final a $72^{\circ} \mathrm{C}$ durante 1 minuto.

Los productos PCR se purificaron por precipitación con polietilenglicol (PEG). La secuenciación del producto de PCR se realizó con un secuenciador multicapilar (16) ABI PRISM 3130XL (Applied Biosystems). Las condiciones de los ciclos de secuenciación fueron: $96^{\circ} \mathrm{C}$ por 5 minutos, seguido por 45 ciclos de $96^{\circ} \mathrm{C}$ durante $10 \mathrm{~s}, 50^{\circ} \mathrm{C}$ durante $5 \mathrm{~s}$, $60^{\circ} \mathrm{C}$ durante 4 minutos y almacenaje indefinido a $4^{\circ} \mathrm{C}$.

Edición y análisis de las secuencias de nucleótidos: Se determinaron las secuencias de consenso alineando por lo menos dos secuencias complementarias, utilizando el programa BioEdit 7.0.9.0 (Hall, 1999). Todas las posiciones fueron corroboradas mediante los cromatogramas. Las secuencias resultantes fueron alineadas utilizando ClustalW 1.4 (Thompson, Higgins, \& Gibson, 1994), incluido en el programa BioEdit. Las alineaciones fueron corroboradas manualmente y las regiones con alineaciones ambiguas fueron descartadas. Las comparaciones de la secuencia entre pares se realizaron mediante el programa MEGA4 (Tamura, Dudley, Nei, \& Kumar, 2007). Para la determinación de la divergencia entre las especies se determinó el porcentaje de diferencia, utilizando todas las bases disponibles en secuencias de igual longitud. El por ciento de divergencia fue la base para el análisis filogenético posterior, construyendo árboles usando el método de vecino más cercano (NeighborJoining) (Saitou, \& Nei, 1987). El programa MEGA4 se utilizó para determinar las secuencias de aminoácidos resultantes de la traducción de los fragmentos de genes, utilizando el código genético mitocondrial de invertebrados.

Los ejemplares tipo fueron depositados en el Museo de Zoología Estatal de Munich (Zoologische Staatssammlung Manchen, ZSM), Alemania y en la Colección Biológica de la Universidad de Puerto Rico en Humacao (CBUPRH).
Sistemática: Según la clasificación de Kaas y Van Belle (1998):

Clase POLYPLACOPHORA Gray, 1821

Orden NEOLORICATA Bergenhayn, 1955

Suborden ISCHNOCHITONINA Bergenhayn, 1930

Familia ISCHNOCHITONIDAE Dall, 1889

Subfamilia LEPIDOCHITONINAE Iredale, 1914

Género Lepidochitona Gray, 1821

Subgénero Lepidochitona s.s.

Lepidochitona (L.) pseudoliozonis GarcíaRíos, sp. nov.

(Figs. 1-11)

\section{MATERIAL EXAMINADO}

Holotipo: ZSM Mol 20130734: Ejemplar completo, aplanado, preservado en etanol, $12.3 \mathrm{~mm}$ de longitud. Estados Unidos de América, Florida, Pigeon Key (2442'10.81" N- 81 ${ }^{\circ} 9^{\prime} 18.16^{\prime}$ W), bajo roca en pradera de hierbas marinas y fondos arenosos, $1 \mathrm{~m}$ de profundidad, recolectado por Migdalia ÁlvarezRuiz y el autor el 18 de noviembre de 2007.

Paratipos: ZSM Mol 20130735: Ejemplar completo, aplanado, preservado en etanol, $11.3 \mathrm{~mm}$ de longitud. Estados Unidos de América, Florida, Pigeon Key (2442'14.97' N$\left.81^{\circ} 9^{\prime} 21.98^{\prime \prime} \mathrm{W}\right)$. Bajo roca en fondo arenoso, $1 \mathrm{~m}$ de profundidad, recolectado por Migdalia Álvarez-Ruiz y el autor el 20 de noviembre de 2007. CBUPRH \#2465: Ejemplar completo, preservado en etanol, $6.2 \mathrm{~mm}$ de longitud. Estados Unidos de América, Florida, Pigeon Key $\left(24^{\circ} 42^{\prime} 15.86^{\prime \prime} \mathrm{N}-81^{\circ} 9^{\prime} 15.71^{\prime}\right.$ W). Bajo roca en fondo arenoso, $1 \mathrm{~m}$ de profundidad, recolectado por Migdalia Álvarez-Ruiz y el autor el 19 de noviembre de 2007. CBUPRH \#2466: $7 \mathrm{~mm}$ de longitud (incluyendo el cinturón), la misma localidad e información de recolección que el ejemplar anterior. CBUPRH \#2467: Ejemplar completo, preservado en etanol, $11.3 \mathrm{~mm}$ de longitud, la misma 
localidad, hábitat e información de recolección que el ejemplar anterior. CBUPUR \#3050: Ejemplar desarticulado, preservado en seco, pie usado para extracción ADN, $11 \mathrm{~mm}$ de longitud, la misma localidad y hábitat que el holotipo, recolectado por Jonathan Sánchez y el autor el 23 de noviembre de 2011. CBUPRH \#3051: Ejemplar completo, preservado en etanol, $9.5 \mathrm{~mm}$ de longitud, la misma localidad, hábitat e información de recolección que el ejemplar anterior. CBUPRH \#3054: $11.1 \mathrm{~mm}$ de longitud (incluyendo el cinturón), la misma localidad e información del ejemplar anterior, preservado en etanol, se removió el pie para extracción ADN. CBUPRH \#3066: $7 \mathrm{~mm}$ de longitud, misma localidad e información que el anterior, preservado en etanol, se removió pie para extracción ADN. CBUPRH 3190: Ejemplar completo, preservado en etanol, $7.3 \mathrm{~mm}$ de longitud, misma localidad e información que el CBUPRH \#3050.

\section{ENGLISH DESCRIPTION OF THE NEW TAXON}

Small animal, holotype $12.3 \mathrm{~mm}$ of total length (Fig. 1), the larger paratypes measure 11.0 to $11.3 \mathrm{~mm}$. The total width (including girdle) of type specimens is greater than half of its total length (average ratio $=59 \%, n=10$ ). However, the ratio of width of the tegmentum of valve IV with the length of the exposed tegmentum of all valves is $44 \%(n=10)$. The girdle is wider at the periphery of the intermediate valves than in the cephalic and anal valves, which accentuates the oval appearance of the species (Fig. 1 and Fig. 2). The dorsal elevation of the valve IV is 0.43 (paratype CBUPRH \#3050); dorsally rounded, without keel in the jugal area, side slope right (Fig. $3 \mathrm{H}$ ). The tegmentum of the holotype is orange, with prominent white band in the ante and postmucronal area. The color of the paratypes mainly orange,

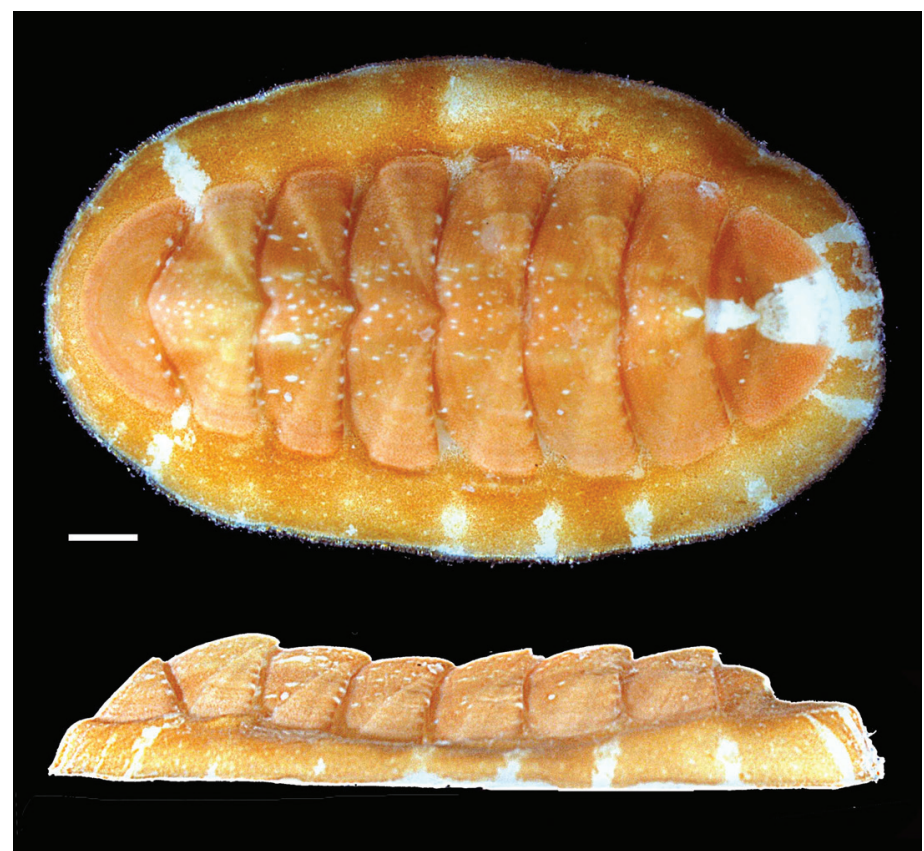

Fig. 1. Lepidochitona pseudoliozonis García-Ríos, sp. nov. Vistas dorsal y lateral del holotipo, ZSM Mol 20130734, longitud de la escala $=1 \mathrm{~mm}$.

Fig. 1. Lepidochitona pseudoliozonis García-Ríos, sp. nov. Dorsal and lateral views of holotype, ZSM Mol 20130734, scale bar $=1 \mathrm{~mm}$. 


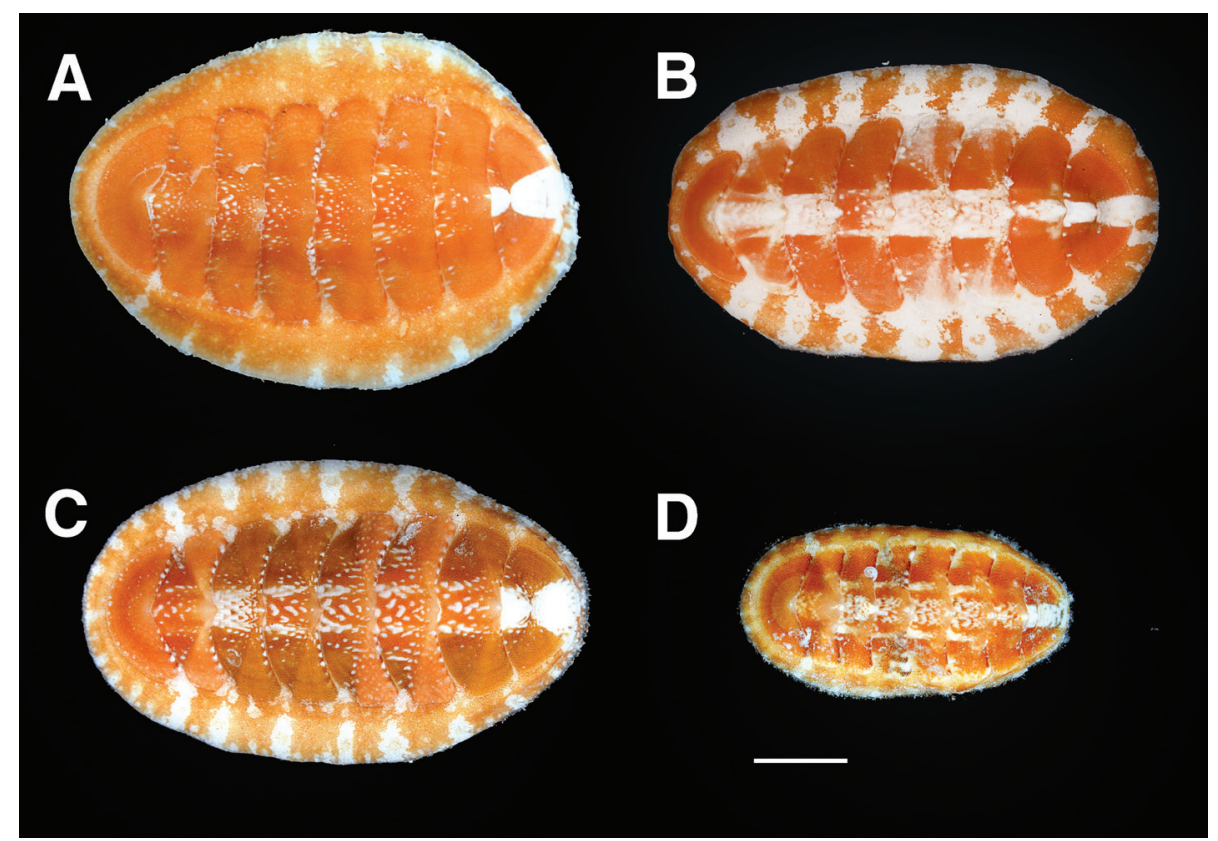

Fig. 2. Lepidochitona pseudoliozonis García-Ríos, sp. nov. Vista dorsal de: (A) paratipo, ZSM Mol 20130735; (B) paratipo, CBUPRH 3050; (C) paratipo, CBUPRH 3054; (D) paratipo, CBUPRH 3066; longitud de la escala=2mm.

Fig. 2. Lepidochitona pseudoliozonis García-Ríos, sp. nov. Dorsal view of: (A) paratype, ZSM Mol 20130735; (B) paratype, CBUPRH 3050; (C) paratype, CBUPRH 3054; (D) paratype, CBUPRH 3066, scale bar=2mm.

from yellowish to reddish orange, with a white patch on the ante and postmucronal area of anal valve (Fig. 2). In the paratypes CBUPRH \#2465, 2467, 3050, 3054, 3066 and 3190 white spots and marks are concentrated in the central area of the intermediate valves, drawing a longitudinal band. The other paratypes have some small points and white spots, mainly in the central areas of the intermediate valves. Paratype CBUPRH \#3066 (Fig. 2D), with longitudinal brown and white banding pattern in the lateral areas of valve IV. The girdle coloration of all the specimens similar to the tegmentum. In some, well defined white and orange bands alternate. These white bands are aligned with the joints of the valves (Fig. 2B and Fig. 2C).

Cephalic valve with semicircular front margin (Fig. 3A). The intermediate valves rectangular, with a slightly concave rear margin on both sides of the apex (Fig. 3B, Fig. 3C y Fig. 3D). Apex defined in all the intermediate valves, most prominent in valves II and III.
Side areas somewhat elevated in valve II, that elevation is reduced in subsequent valves (Fig. 3B, Fig. 3C y Fig. 3D). Surface of tegmentum of smooth appearance. Fine concentric growth lines, cut by pores lines in radial arrangement (aesthetes) may be seen under the microscope (Fig. 3). Anal and cephalic valves of similar width, 30\% narrower than valve IV (Fig. 3A and Fig. 3E). Anal valve with tegmentum twice wider than long, with semicircular posterior edge and the straight front edge (Fig. 3E). Prominent mucro, in central position. The postmucronal slope concave (Fig. 3I). Esthetes density of $3.150 / \mathrm{mm}^{2} \pm 300$ (Fig. 4).

Articulamentum whitish, transparent (Fig. 5). The insertion plates short, irregular in size, with slit formula of 9/1/10 ( $n=3)$. Apophyses more triangular and pointed at valve II, a little less in the third, more rectangular in posterior valves. Apophyses well separated, jugal sinus approximately one-third of the width of the valve (Fig. 3 and Fig. 5). Jugal sinus of 


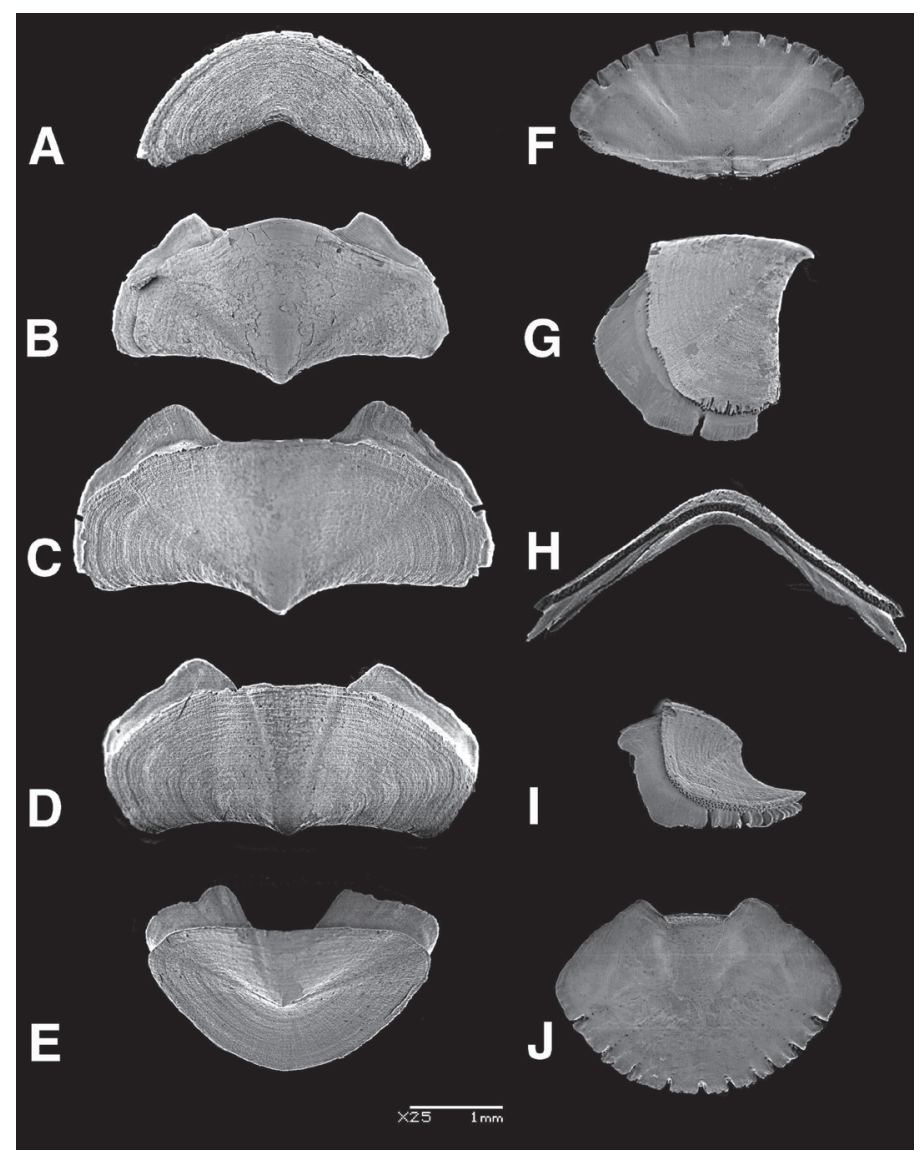

Fig. 3. Lepidochitona pseudoliozonis García-Ríos, sp. nov. Longitud del ejemplar, incluyendo el cinturón, $11 \mathrm{~mm}$. Paratipo CBUPRH \#3050; vista dorsal de: (A) valva cefálica; (B) valva II; (C) valva IV; (D) valva VII; (E) valva anal; (F) vista ventral de la valva cefálica; $(\mathrm{G})$ vista lateral de la valva II; $(\mathrm{H})$ vista frontal de la valva IV; (I) vista lateral de la valva anal; (J) vista ventral de la valva anal.

Fig. 3. Lepidochitona pseudoliozonis García-Ríos, sp. nov. Whole specimen $11 \mathrm{~mm}$ long, including girdle. Paratype CBUPRH \#3050; dorsal view of: (A) head valve; (B) valve II; (C) valve IV; (D) valve VII; (E) tail valve; (F) head valve, ventral view; (G) valve II, lateral view; $(\mathrm{H})$ valve IV, frontal view; (I) tail valve, lateral view; (J) tail valve, ventral view.

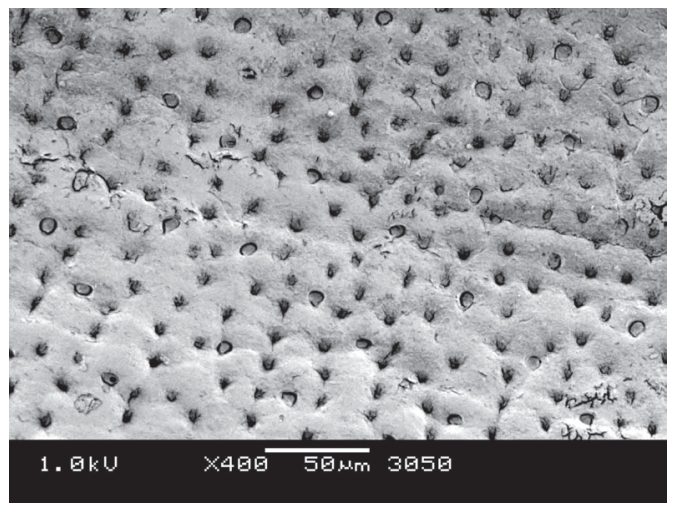

intermediate valves straight, except in valve II, which is convex. The eaves of all the valves are very porous (Fig. 6).

The dorsal surface of the girdle is covered by colored cylindrical corpuscles with rounded heads, separate from one another (Fig. 7).

Fig. 4. Lepidochitona pseudoliozonis García-Ríos, sp. nov. Paratipo CBUPRH \#3050: detalle del tegumento de la valva anal.

Fig. 4. Lepidochitona pseudoliozonis García-Ríos, sp. nov. Paratype CBUPRH \#3050: detail of tegmentum of tail valve. 


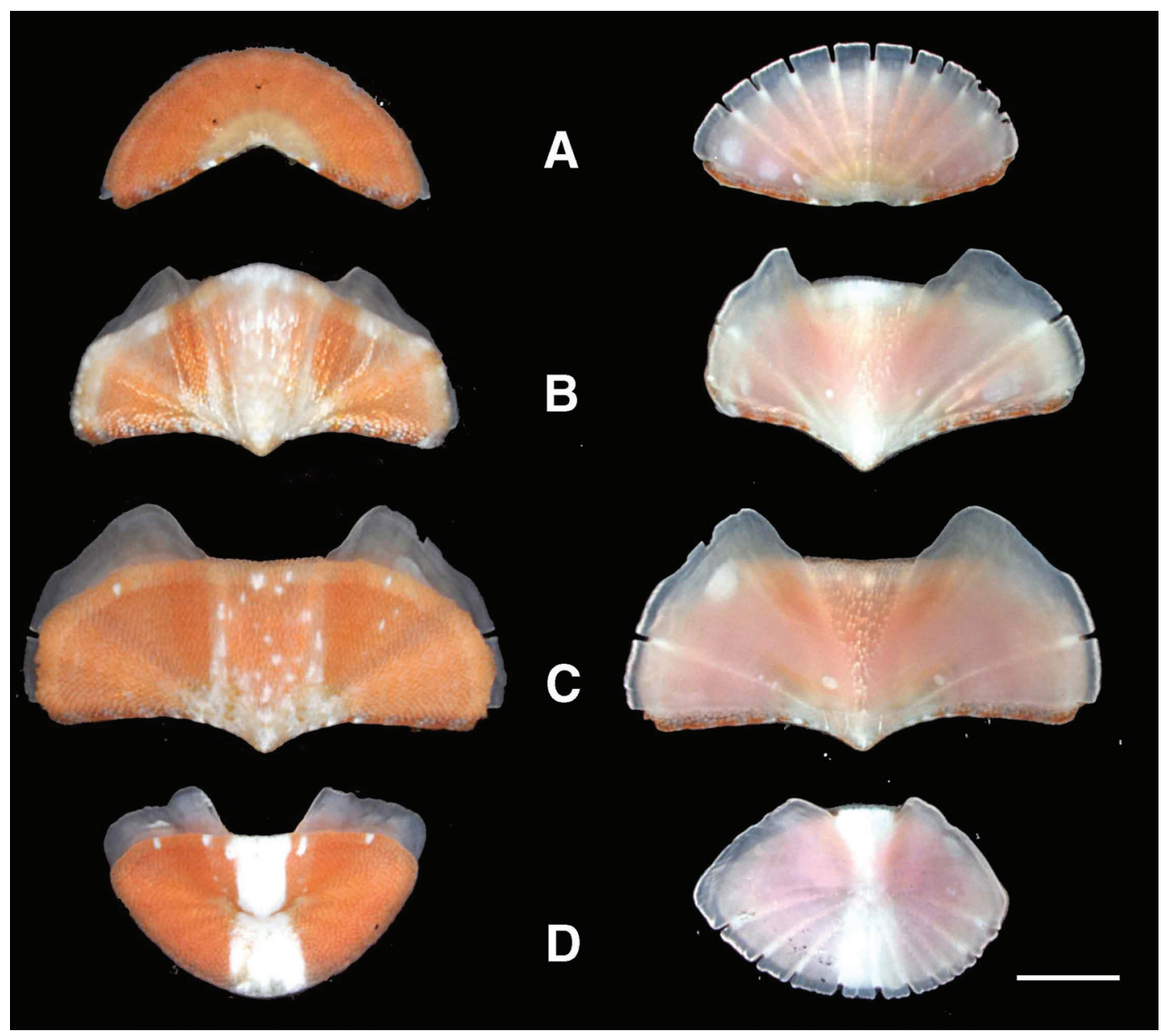

Fig. 5. Lepidochitona pseudoliozonis García-Ríos, sp. nov. Paratipo CBUPRH \#3050: a la izquierda, vista dorsal, a la derecha, vista ventral de: (A) valva cefálica; (B) valva II; (C) valva IV; (D) valva anal; longitud de la escala=1 $\mathrm{mm}$.

Fig. 5. Lepidochitona pseudoliozonis García-Ríos, sp. nov. Paratype CBUPRH \#3050: left, dorsal view, right, ventral view of: (A) head valve; (B) valve II; (C) valve IV; (D) tail valve; scale bar=1mm.

These corpuscles have around $13 \mu \mathrm{m}$ diameter and approximately $30 \mu \mathrm{m}$ of length. Around the girdle hyaline spicules are distributed (Fig. 8), mostly aligned with the sutures of the valves. These hyaline spicules can reach up to $300 \mu \mathrm{m}$, smaller ones are scattered on the dorsal surface of the girdle. The outer margin of the belt is surrounded by a row of transparent spicules, some whitish, and other yellowish. The marginal spicules measured around $100 \mu \mathrm{m}$ in length and around $20 \mu \mathrm{m}$ in diameter at the base. Marginal spicules are flat on the ventral surface, and vaulted on its dorsal face, striated lengthwise (Fig. 9 and Fig. 10C). The ventral side of the girdle is covered with transparent overlapping spicules, with the tips pointing towards the outer edge. The ventral spicules situated closest to the margin are larger, with lengths of $40 \mu \mathrm{m}$ and some $15 \mu \mathrm{m}$ in width at the base (Fig. 10A). Between the ventral and marginal spicules there is a row of submarginal, semirectangular scales of $70 \mu \mathrm{m}$ of length and $20 \mu \mathrm{m}$ of width (Fig. 10B).

Radulae of paratype CBUPRH \#3050 has 19 rows of mineralized tooth, two partially mineralized and 6 rows of immature teeth. 


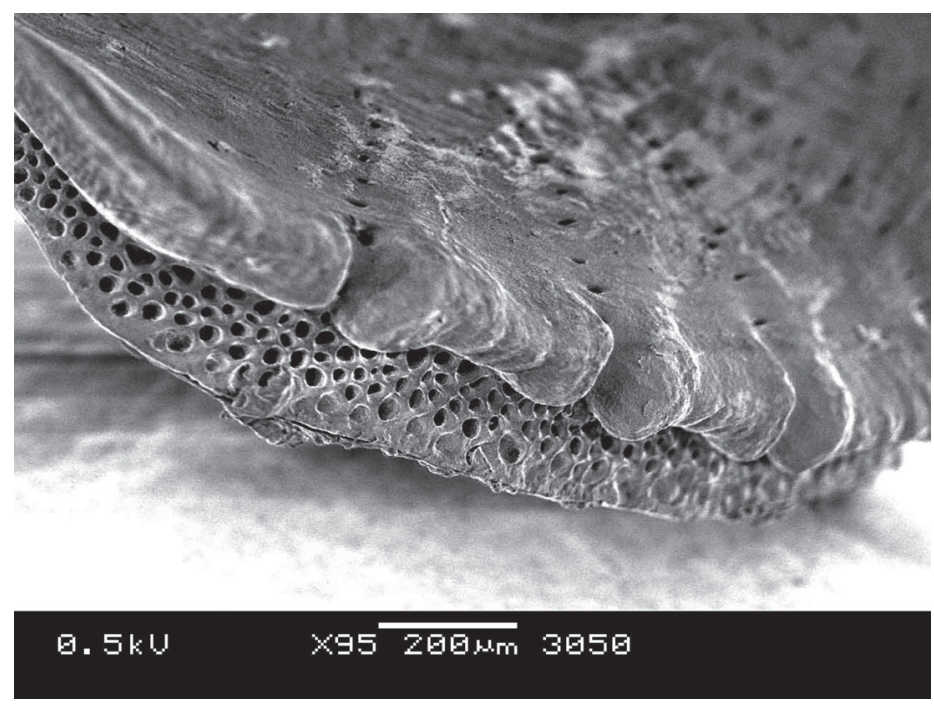

Fig. 6. Lepidochitona pseudoliozonis García-Ríos, sp. nov. Paratipo CBUPRH \#3050: detalles del alero y de la placa de inserción de la valva IV.

Fig. 6. Lepidochitona pseudoliozonis García-Ríos, sp. nov. Paratype CBUPRH \#3050: details of eaves and insertion plates of valve IV.

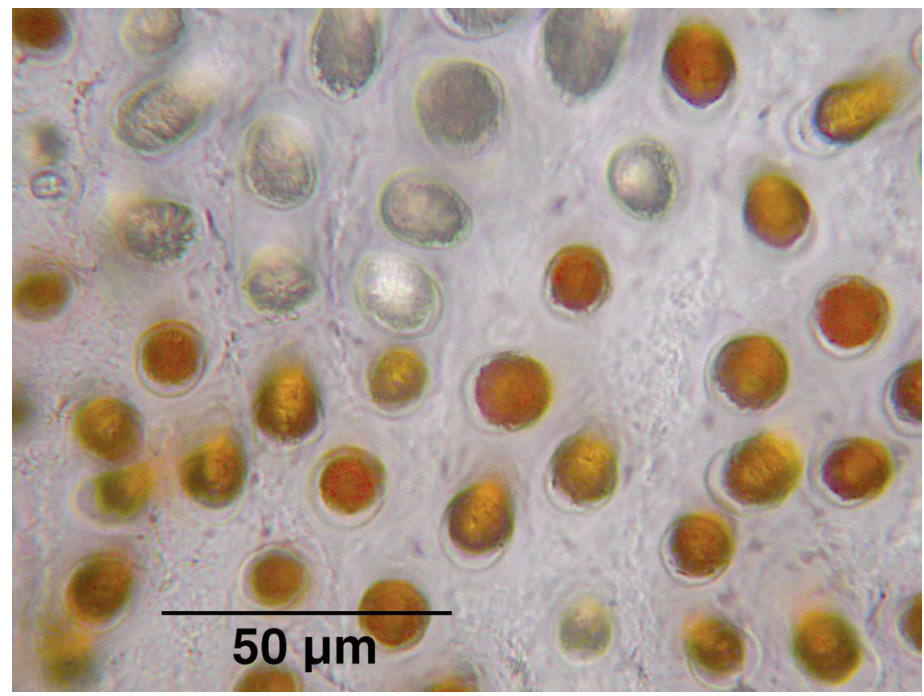

Fig. 7. Lepidochitona pseudoliozonis García-Ríos, sp. nov. Paratipo CBUPRH \#3050: corpúsculos coloreados en la superficie dorsal del cinturón.

Fig. 7. Lepidochitona pseudoliozonis García-Ríos, sp. nov. Paratype CBUPRH \#3050: colored corpuscles in girdle dorsal surface. 


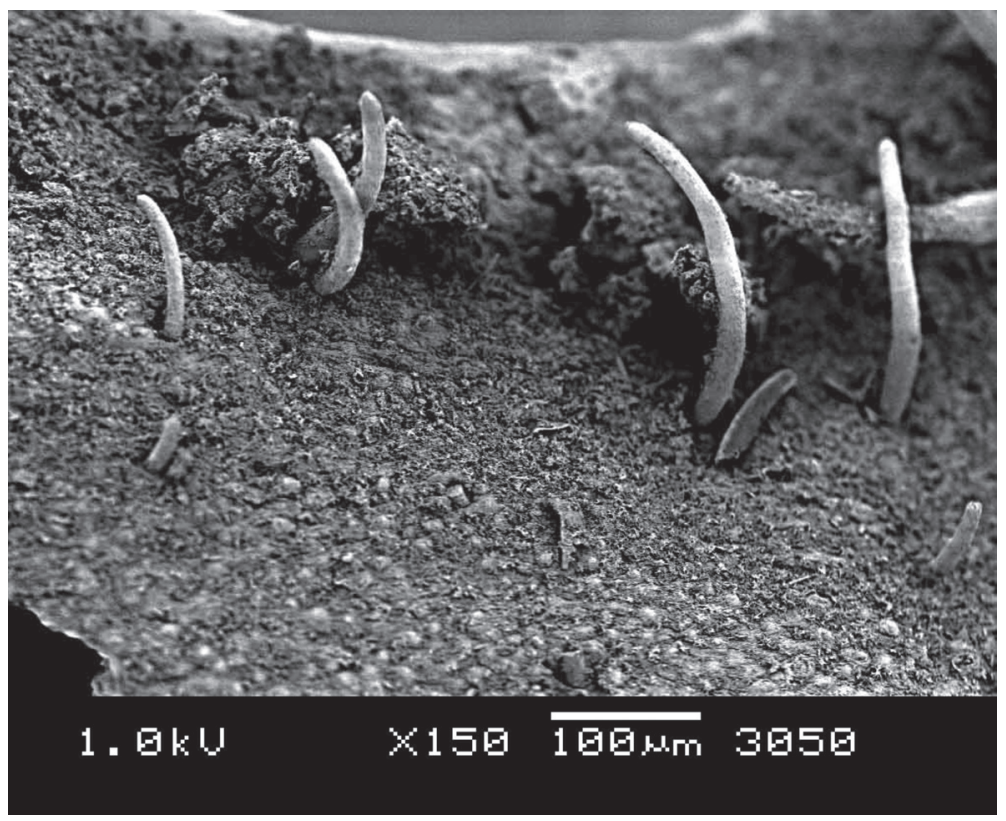

Fig. 8. Lepidochitona pseudoliozonis García-Ríos, sp. nov. Paratipo CBUPRH \#3050: espículas hialinas en la superficie dorsal del cinturón.

Fig. 8. Lepidochitona pseudoliozonis García-Ríos, sp. nov. Paratype CBUPRH \#3050: hyaline spicules in girdle dorsal surface.

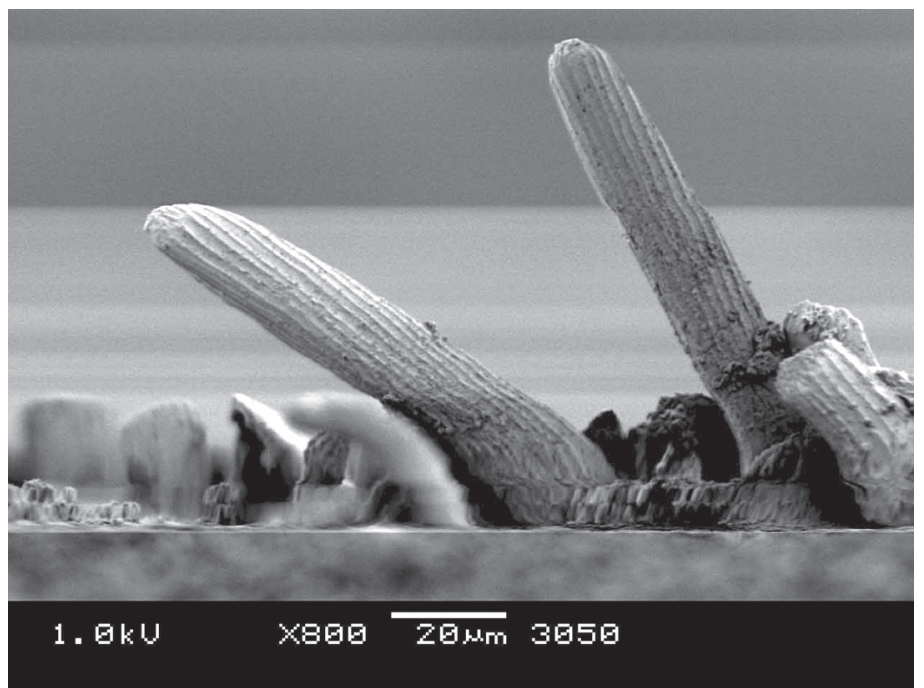

Fig. 9. Lepidochitona pseudoliozonis García-Ríos, sp. nov. Paratipo CBUPRH \#3050: vista dorsal de las espículas marginales del cinturón.

Fig. 9. Lepidochitona pseudoliozonis García-Ríos, sp. nov. Paratype CBUPRH \#3050: dorsal view of girdle marginal spicules. 


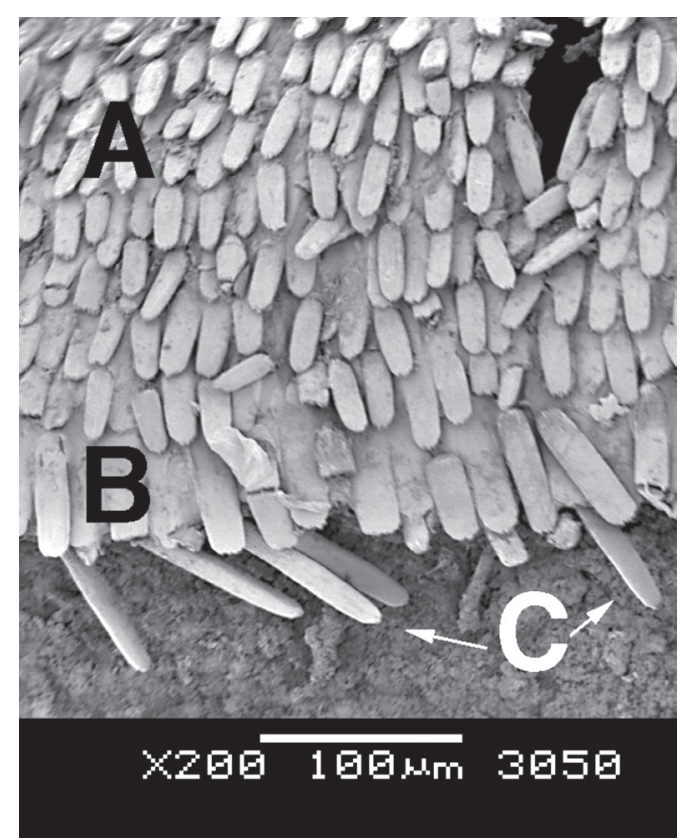

Fig. 10. Lepidochitona pseudoliozonis García-Ríos, sp. nov. Paratipo CBUPRH \#3050: vista ventral del cinturón: (A) espículas ventrales; (B) espículas submarginales; (C) espículas marginales.

Fig. 10. Lepidochitona pseudoliozonis García-Ríos, sp. nov. Paratype CBUPRH \#3050: ventral view of girdle: (A) ventral spicules; (B) submarginal spicules; (C) marginal spicules.
The rhachidian tooth approximately $30 \mu \mathrm{m}$ at its wider end. Major lateral tooth is tricuspid, $50 \mu \mathrm{m}$ of width, the central cusp slightly longer, spatulate uncinal teeth have hooked distal end (Fig. 11).

The holotype with 13 pairs of gills, while in the paratypes there are 12-10 pairs. Gills occupy the posterior half of the pallial groove (merobranchial) and increase in size posteriorly (abanal).

The sequences of the mitochondrial gene coding for cytochrome oxidase I (COI) of the paratypes CBUPRH \#3050, \#3054 and \#3066 are deposited in the GenBank (accession numbers on Table 1). The comparison of sequences of L. liozonis (Puerto Rico, $\mathrm{n}=4$ ), L. bullocki (Colombia, $\mathrm{n}=2$ ) and L. pseudoliozonis (Florida, $n=3$ ) show similar genetic distances between the three species. The lower divergence (13.7-14.1\%) appear among L. liozonis and L. pseudoliozonis; 16.3 to16.5\% between $L$. bullocki and two sibling species (Fig. 12). A fragment of $658 \mathrm{bp}$ of COI gene from paratype CBUPRH \#3050 is presented here also:

$\begin{array}{llllll}\text { AACCCTTTAT } & \text { TTAATTTTTG } & \text { GTGTATGATC } & \text { AGGATTAGTT } & \text { GGGACTGCCC } & \text { TTAGATTATT } \\ \text { AATTCGATTT } & \text { GAATTAAGTC } & \text { ATCCAGGGTC } & \text { ATTCATTGGA } & \text { GATGAACAAA } & \text { TTTATAATGT } \\ \text { AATTATTACA } & \text { GCTCATGCTT } & \text { TTGTAATAAT } & \text { TTTTTTTTA } & \text { GTAATACCAA } & \text { TAATAATTGG } \\ \text { AGGATTTGGG } & \text { AATTGATTAG } & \text { TCCCTATAAT } & \text { GTTAGGAGCC } & \text { CCTGATATGG } & \text { CATTTCCTCG } \\ \text { AATAAATAAT } & \text { ATAAGATTCT } & \text { GGCTTCTCCC } & \text { ACCAGCTTTA } & \text { TCTCTCTTAT } & \text { TAAGTTCTGC } \\ \text { TGCTGTAGAA } & \text { AGAGGAGTGG } & \text { GAACTGGTTG } & \text { AACAGTATAT } & \text { CCACCATTAG } & \text { CAAGAAATTT } \\ \text { GGCTCATGCA } & \text { GGAGGAGCAG } & \text { TAGATTTAGC } & \text { AATCTTTCT } & \text { TTACATTTAG } & \text { CAGGAGTTC } \\ \text { ATCTATTTTA } & \text { GGTGCTGCTA } & \text { ATTTTATTTC } & \text { TACGATTTT } & \text { AATATACGAT } & \text { GAAAGGGTTT } \\ \text { AACATTAGAA } & \text { CAAATACCAT } & \text { TATTTGTTTG } & \text { ATCTGTTCTT } & \text { ATTACTGCTG } & \text { TTTTATTGTT } \\ \text { ACTATCACTT } & \text { CCTGTTTTAG } & \text { CGGGAGCTAT } & \text { TACAATACTT } & \text { CTAACAGATC } & \text { GAAATTTTAA } \\ \text { CACATCTTTT } & \text { TTTGACCCAG } & \text { CAGGAGGAGG } & \text { AGATCCTGTA } & \text { TTATATCAAC } & \text { ACTTATTC }\end{array}$

\section{DESCRIPCIÓN DE LA ESPECIE}

Animal pequeño, holotipo mide $12.3 \mathrm{~mm}$ de longitud total (Fig. 1), los tres paratipos de mayor tamaño miden de 11.0 a $11.3 \mathrm{~mm}$. El ancho total (incluyendo el cinturón) de todos los ejemplares tipo es mayor que la mitad de su longitud total (proporción promedio $=59 \%$, $\mathrm{n}=10$ ). Sin embargo, la relación de ancho del tegumento de la valva IV con el largo del tegumento expuesto de todas las valvas es de $44 \%(n=10)$. El cinturón es más ancho en la periferia de las valvas intermedias que en las valvas cefálica y anal, lo que acentúa la 


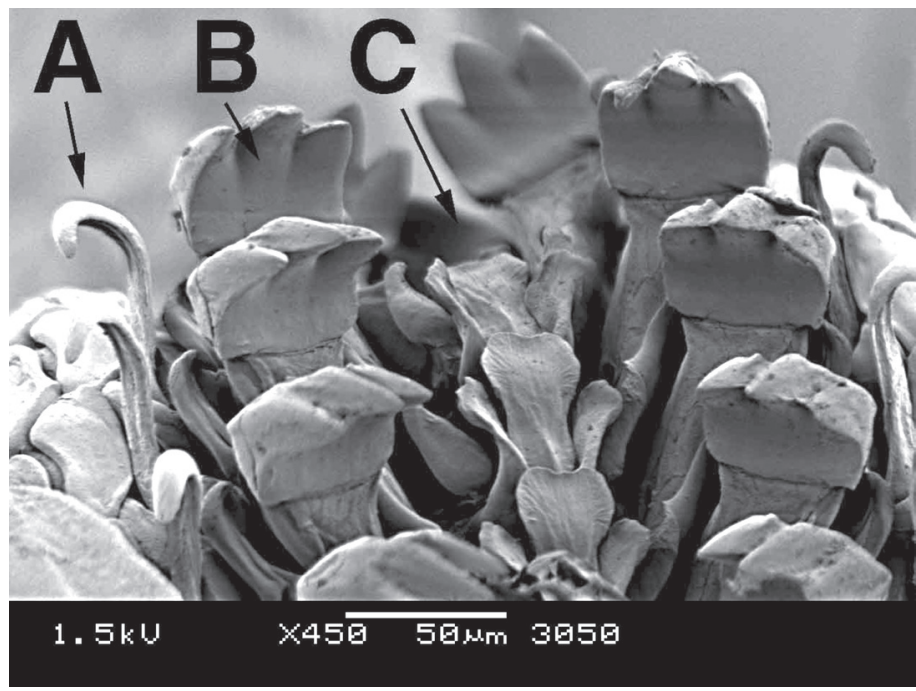

Fig. 11. Lepidochitona pseudoliozonis García-Ríos, sp. nov. Paratipo CBUPRH \#3050: rádula: (A) diente unicino espatulado; (B) diente lateral mayor; (C) diente central.

Fig. 11. Lepidochitona pseudoliozonis García-Ríos, sp. nov. Paratype CBUPRH \#3050: radula: (A) spatulate uncinal tooth; (B) major lateral tooth; (C) rhachidian tooth.

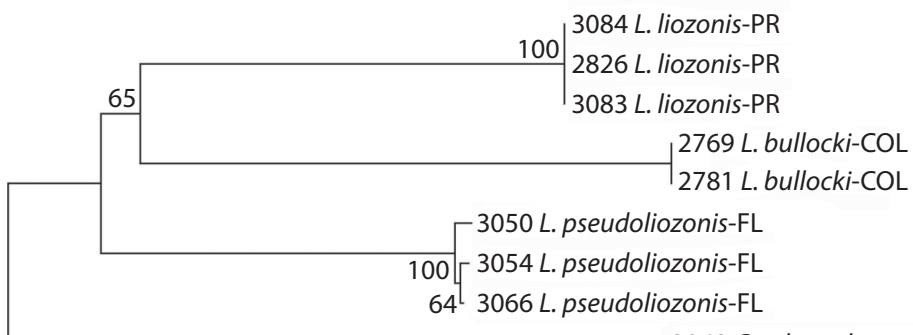

3068 C. tuberculatus-raíz

0.02

Fig. 12. Árbol filogenético de poblaciones de Lepidochitona spp. del Caribe, basado en el porcentaje de distancia de 526 bp del gen mitocondrial COI. La relación evolutiva se infiere usando el método vecino más cercano. El porcentaje de réplicas de las asociaciones entre taxones, a partir un análisis de bootstrap de 1000, aparece cercano a las ramas. Chiton tuberculatus se utiliza como raíz. $\mathrm{COL}=$ Colombia, $\mathrm{PR}=$ Puerto Rico, $\mathrm{FL}=$ Florida.

Fig. 12. Phylogenetic tree of Caribbean Lepidochitona spp. based on $526 \mathrm{bp}$ of the COI gene, using nucleotide percent distance. The evolutionary relationship was inferred using the Neighbor-Joining method. Values at nodes represent the percentage of 1000 bootstrap replicates. Tree is rooted with Chiton tuberculatus. $\mathrm{COL}=\mathrm{Colombia}, \mathrm{PR}=\mathrm{Puerto}$ Rico, $\mathrm{FL}=$ Florida. 
apariencia ovalada de la especie (Fig. 1 y Fig. 2). La elevación dorsal de la valva IV es de 0.43 (ejemplar CBUPRH \#3050); dorsalmente redondeada, sin carina en la región del yugo, pendiente lateral derecha (Fig. 3H). El tegumento del holotipo es color anaranjado, con una prominente mancha blanca en las áreas pre y posmucronal. Todos los paratipos con tegumento principalmente anaranjado, desde anaranjado amarillento a anaranjado rojizo. Todos con una mancha blanca en las zonas pre y posmucrón de la valva anal (Fig. 2). En los paratipos CBUPRH\# 2465, 2467, 3050, 3054, 3066 y 3190 hay marcas y puntos blancos que se concentran en el área central de las valvas intermedias, dibujando una banda longitudinal. En todos los ejemplares se pueden observar algunos pequeños puntos y manchas claras, principalmente en las áreas centrales de las valvas intermedias. El paratipo CBUPRH \#3066 (Fig. 2D) presenta un patrón de bandas longitudinales, marrones y blancas, en áreas laterales de la valva IV. El cinturón de todos los tipos tiene coloración similar al tegumento. En algunos se definen bandas claras alternando con bandas coloreadas de anaranjado, esas bandas claras coinciden con las uniones de las valvas (Fig. 2B y Fig. 2C).

La valva cefálica con el borde anterior semicircular (Fig. 3A). Las valvas intermedias rectangulares, con el margen posterior algo cóncavo a ambos lados del ápice (Fig. 3B, Fig. 3C y Fig. 3D). El ápice definido en todas las valvas intermedias, más prominente en las valvas II y III. Las áreas laterales algo elevadas en la valva II, esa elevación se reduce en valvas posteriores (Fig. 3B, Fig. 3C, Fig. 3D). La superficie del tegumento de apariencia lisa, bajo el microscopio se pueden observar líneas de crecimiento concéntricas, cortadas por los estetos alineados en arreglo radial (Fig. 3). La valva anal y cefálica son de ancho similar y $30 \%$ más estrechas que la valva IV (Fig. 3A y Fig. 3E). La valva anal presenta tegumento dos veces más ancho que largo, así como un borde posterior semicircular y el borde anterior recto (Fig. 3E). El mucro es prominente, en posición central. La pendiente posmucronal cóncava
(Fig. 3I). Los estetos en densidades de 3000/ $\mathrm{mm}^{2} \pm 300$ (Fig. 4).

El articulamento es claro y transparente (Fig. 5). La placa de inserción corta, con fórmula de $9 / 1 / 10(n=3)$, las hendiduras no son equidistantes. La apófisis son de forma más triangular y puntiaguda en la valva II, un poco menos en la III, más rectangulares en las valvas posteriores. Las apófisis se encuentran bien separadas, el seno del yugo de aproximadamente un tercio del ancho de la valva (Fig. 3, Fig. 4 y Fig. 5). El seno del yugo de las valvas intermedias es derecho, excepto en la valva II, que es convexo. Los aleros de las valvas son muy porosos (Fig. 6).

La superficie dorsal del cinturón está cubierta por las cabezas redondeadas de corpúsculos cilíndricos coloreados (Fig. 7), separados unos de otros. Estos corpúsculos tienen alrededor de $13 \mu \mathrm{m}$ diámetro y aproximadamente $30 \mu \mathrm{m}$ de longitud. Alrededor del cinturón se distribuyen mechones de espículas hialinas (Fig. 8), la mayoría alineadas con las suturas de las valvas. Estas espículas hialinas pueden alcanzar los $300 \mu \mathrm{m}$, otras más pequeñas se encuentran dispersas sobre el cinturón. El margen exterior del cinturón está rodeado de una fila de espículas transparentes, algunas blanquecinas, otras amarillentas. Estas espículas marginales miden alrededor de $100 \mu \mathrm{m}$ de longitud y alrededor de $20 \mu \mathrm{m}$ de diámetro en la base. Las espículas marginales son planas en su extremo ventral y abovedadas en su cara dorsal, esa superficie dorsal de las espículas está estriada longitudinalmente (Fig. 9 y Fig. 10C). Ventralmente, el cinturón está cubierto por espículas transparentes, solapadas, con las puntas orientadas hacia el margen exterior. Las más cercanas al margen son más grandes, con longitudes de $40 \mu \mathrm{m}$ y unos $15 \mu \mathrm{m}$ de ancho en la base (Fig. 10A). Entre las espículas ventrales y las marginales se encuentra una fila de escamas submarginales, semirectangulares, de unos $70 \mu \mathrm{m}$ de longitud y $20 \mu \mathrm{m}$ de ancho (Fig. 10B).

El paratipo CBUPRH \#3050 tiene 19 filas de dientes mineralizados, dos parcialmente mineralizados y 6 filas de dientes inmaduros. El diente central mide aproximadamente $30 \mu \mathrm{m}$ en su extremo más ancho. El diente lateral 
mayor tricúspide, mide $50 \mu \mathrm{m}$ de ancho, la cúspide central un poco más larga. Los dientes unciformes espatulados tienen su extremo distal curvo (Fig. 11).

En el holotipo hay 13 pares de branquias, mientras que en los paratipos hay de 12 a 10 pares. Las branquias anteriores ubican bajo la valva IV y se extienden hasta cerca del inicio de la valva anal (arreglo merobranquial), y aumentan de tamaño hacia el extremo posterior (abanal).

Las secuencias del gen mitocondrial que codifica para el citocromo oxidasa I (COI) de los paratipos CBUPRH \#3050, \#3054 y \#3066 se depositaron en el GenBank (números de acceso en el Cuadro 1). La comparación de las secuencias de L. liozonis (Puerto Rico, $\mathrm{n}=4$ ), $L$. bullocki (Colombia, $\mathrm{n}=2$ ) y L. pseudoliozonis (Florida, $\mathrm{n}=3$ ) permitió determinar distancias genéticas de magnitud similar entre las tres especies. La menor divergencia (13.7 a 14.1\%) aparece entre L. liozonis y L. pseudoliozonis; 16.3 a $16.5 \%$ entre L. bullocki y las dos especies gemelas (Fig. 12). Una secuencia de 658 nucleótidos del gen COI del paratipo CBUPRH \#3050 se presenta aquí también:

\begin{tabular}{llllll}
\hline AACCCTTTAT & TTAATTTTTG & GTGTATGATC & AGGATTAGTT & GGGACTGCCC & TTAGATTATT \\
AATTCGATTT & GAATTAAGTC & ATCCAGGGTC & ATTCATTGGA & GATGAACAAA & TTTATAATGT \\
AATTATTACA & GCTCATGCTT & TTGTAATAAT & TTTTTTTTA & GTAATACCAA & TAATAATTGG \\
AGGATTTGGG & AATTGATTAG & TCCCTATAAT & GTTAGGAGCC & CCTGATATGG & CATTTCCTCG \\
AATAAATAAT & ATAAGATTCT & GGCTTCTCCC & ACCAGCTTTA & TCTCTCTTAT & TAAGTTCTGC \\
TGCTGTAGAA & AGAGGAGTGG & GAACTGGTTG & AACAGTATAT & CCACCATTAG & CAAGAAATTT \\
GGCTCATGCA & GGAGGAGCAG & TAGATTTAGC & AATCTTTTCT & TTACATTTAG & CAGGAGTTTC \\
ATCTATTTTA & GGTGCTGCTA & ATTTTATTTC & TACGATTTTT & AATATACGAT & GAAAGGGTT \\
AACATTAGAA & CAAATACCAT & TATTTGTTTG & ATCTGTTCTT & ATTACTGCTG & TTTTATTGTT \\
ACTATCACTT & CCTGTTTAG & CGGGAGCTAT & TACAATACTT & CTAACAGATC & GAAATTTTAA \\
CACATCTTTT & TTTGACCCAG & CAGGAGGAGG & AGATCCTGTA & TTATATCAAC & ACTTATTC
\end{tabular}

CUADRO 1

Ejemplares y número de acceso del GenBank

TABLE 1

Specimens and GenBank accession numbers

\begin{tabular}{|c|c|c|c|}
\hline Especies & Localidad & Acces no. & CBUPRH no. \\
\hline L. pseudoliozonis & Florida - Pigeon Key $24^{\circ} 42^{\prime} 10.81^{\prime \prime} \mathrm{N}, 81^{\circ} 9^{\prime} 18.16^{\prime \prime} \mathrm{W}$ & KJ872765 & 3050 \\
\hline L. pseudoliozonis & Florida - Pigeon Key $24^{\circ} 42^{\prime} 10.81^{\prime}$ N, $81^{\circ} 9^{\prime} 18.16^{\prime \prime} \mathrm{W}$ & KJ872766 & 3054 \\
\hline L. pseudoliozonis & Florida - Pigeon Key $24^{\circ} 42^{\prime} 10.81^{\prime}{ }^{\prime} \mathrm{N}, 81^{\circ} 9^{\prime} 18.16^{\prime \prime} \mathrm{W}$ & KJ872767 & 3066 \\
\hline L. liozonis & Puerto Rico - Lajas, $17^{\circ} 57^{\prime} 27.36^{\prime \prime} \mathrm{N}, 67^{\circ} 2^{\prime} 31.53^{\prime \prime} \mathrm{W}$ & KJ872764 & 2826 \\
\hline L. liozonis & Puerto Rico - Naguabo, $18^{\circ} 11^{\prime} 3.33^{\prime \prime} \mathrm{N}, 65^{\circ} 42^{\prime} 19.76^{\prime \prime} \mathrm{W}$ & KJ872768 & 3083 \\
\hline L. liozonis & Puerto Rico - Naguabo, $18^{\circ} 11^{\prime} 3.33^{\prime \prime} \mathrm{N}, 65^{\circ} 42^{\prime} 19.76^{\prime \prime} \mathrm{W}$ & KJ872769 & 3084 \\
\hline L. bullocki & Colombia - Santa Marta, $11^{\circ} 12>25.98 » \mathrm{~N}, 74^{\circ} 13^{\prime} 48.65^{\prime \prime} \mathrm{W}$ & KJ872762 & 2769 \\
\hline L. bullocki & Colombia - Santa Marta, $11^{\circ} 12^{\prime} 27.25^{\prime \prime} \mathrm{N}, 7^{\circ} 13^{\prime} 47.28^{\prime \prime} \mathrm{W}$ & KJ872763 & 2781 \\
\hline C. tuberculatus & Bermuda - Pokiok Rd., $32^{\circ} 18^{\prime} 26.16^{\prime \prime} \mathrm{N}, 64^{\circ} 43^{\prime} 55.67^{\prime}$ W & KJ909661 & 3068 \\
\hline
\end{tabular}


Etimología: Esta especie incluye un subconjunto de lo que anteriormente se clasificó como L. liozonis. Siendo tan similar en morfología, fuera del contexto geográfico es fácil confundirlas, la nombramos la falsa liozonis: pseudoliozonis.

Diferencias con otros lepidoquitones del Caribe: L. pseudoliozonis difiere de las otras tres especies de lepidoquitones del Caribe en su mayor tamaño. L. pseudoliozonis carece de densos mechones de largas espículas hialinas $(>400 \mu \mathrm{m})$ como los tiene L. bullocki. El tegumento, con superficie lisa, con muy pocas irregularidades, lo distingue de L. rufoi. La pendiente posmucronal cóncava lo diferencia de L. rosea (Fig. 13).

\section{DISCUSIÓN}

El número de especies crípticas, taxones muy similares morfológicamente pero genéticamente distintos, es subestimado en el medio marino (Knowlton, 2000). Esto es así por la aparente ausencia de barreras que impidan la dispersión de las especies. Lepidochitona pseudoliozonis fue inicialmente identificada como una especie críptica de L. liozonis. La muestra de L. pseudoliozonis proviene de Pigeon Key, Florida; cerca del extremo norte de la distribución que se le atribuyó a $L$. liozonis. La muestra que se utilizó, para establecer la divergencia genética entre ambas especies, es de Puerto Rico, la localidad tipo de L. liozonis. Se encontró un por ciento de divergencia de 13.7 a 14.1. Esa distancia genética es mayor al promedio de la distancia encontrada entre 20 especies de otro género de poliplacóforos, Mopalia Gray, 1847, al comparar secuencias del gen COI (12\%, N=190) (Kelly, Sarkar, Eernisse, \& Desalle, 2007). Si aplicamos la calibración de la secuencia del COI realizada para quitones del género Stenoplax y Acantochitona (García-Ríos, Pérez-Pérez, FernándezLópez, \& Fuentes, 2014) podemos decir que $L$. liozonis y L. pseudoliozonis quedaron aisladas hace alrededor de 8 millones de años, antes del cierre parcial del istmo de Panamá.

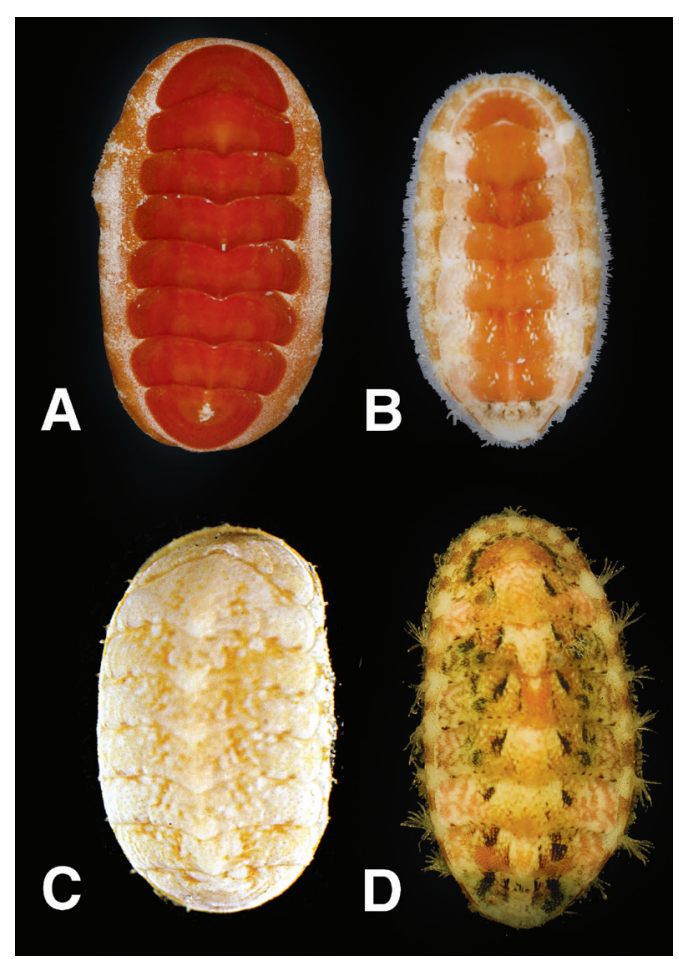

Fig. 13. Lepidoquitones del Caribe: (A) Lepidochitona liozonis (Dall \& Simpson, 1901), Puerto Rico, CBUPRH 2409, longitud total=7.6mm; (B) L. rosea Kaas, 1972, Tobago, CBUPRH 2430, largo total $=6.5 \mathrm{~mm}$; (C) $L$. rufoi García Ríos, 2010, Puerto Rico, paratipo ZSM Mol 20090398, longitud total=3mm; (D) L. bullocki GarcíaRíos, 2011, Colombia, holotipo ZSM Mol 20100542, longitud total $=5.5 \mathrm{~mm}$.

Fig. 13. Lepidochitons of the Caribbean: (A) Lepidochitona liozonis (Dall \& Simpson, 1901), Puerto Rico, CBUPRH 2409, total length=7.6mm; (B) (B) L. rosea Kaas, 1972, Tobago, CBUPRH 2430, total length $=6.5 \mathrm{~mm}$; (C) $L$. rufoi García Ríos, 2010, Puerto Rico, paratype ZSM Mol 20090398, total length=3mm; (D) L. bullocki García-Ríos, 2011, Colombia, holotype ZSM Mol 20100542, total length $=5.5 \mathrm{~mm}$.

La secuencia del COI, desde la posición 1 515 hasta la 2172 (658bp) del ejemplar \#3084 L. liozonis (Puerto Rico) comparada con el ejemplar \#3050 L. pseudoliozonis (Florida) permitió identificar 99 posiciones variables (55 transiciones y 44 transversiones), lo que equivale a una divergencia de $15 \%$ bp $(\mathrm{SE}=0.014)$. Utilizando el segundo nucleótido como inicio de la traducción, se produce una secuencia 
de 219 aminoácidos (código mitocondrial de invertebrados) con 4 posiciones variables, localizadas en la posición 8 (I-V), 13 (A-V), 94 (C-S) y 123 (S-A) de la secuencia. Esto contrasta con la variabilidad entre especies cercanas, que presentan mutaciones ciegas en el gen COI (datos sin publicar). El por ciento de divergencia encontrado compara con distancia entre géneros, en otros taxones (Ward, 2009).

El tamaño de L. pseudoliozonis es el atributo morfológico que advierte una diferencia con L. liozonis. En una muestra de 10 ejemplares, L. pseudoliozonis tiene un tamaño promedio de $9.24 \mathrm{~mm}$, mientras que el tamaño promedio de una muestra de L. liozonis es de $7 \mathrm{~mm}(\mathrm{n}=40)$, aunque se informan ejemplares que alcanzan los 14.4mm (García-Ríos, 2003). Kaas (1972) examinó una muestra de cuatro ejemplares de Bonefish Key (actualmente Fat Deer Key) y lo primero que menciona es que son más grandes que los ejemplares de L. liozonis.

Los ejemplares que Kaas (1972) examinó fueron recolectados aproximadamente a $15 \mathrm{~km}$ al este de la localidad del lote que aquí se describe. Son morfológicamente similares a nuestra muestra, excepto por el color. Kaas (1972) describe a L. liozonis var. tropica como de color oliva, verdosa o marrón rojizo. Redfern (2013) muestra fotografías de ejemplares de Bahamas con tegumento verde. Ninguno de los 10 ejemplares que examinamos para esta descripción es verdoso o presenta manchas verdosas. Tampoco encontramos ejemplares marrón rojizo, como el paratipo ilustrado entero en la descripción original. Sin embargo, la valva anal de otro de los paratipos es compatible con la forma y color de la especie que aquí describimos.

Redfern (2013) se refiere a L. liozonis en Abaco, Bahamas, como el quitón camaleónico, haciendo alusión a su capacidad de variar su coloración, desde un rojo muy intenso, purpúreo hasta anaranjado claro. Cuando están sobre algas rojas coralinas de tipo crustoso pueden mimetizarlas (García-Ríos, 2006; Littler, \& Littler, 2000). Estos cambios en coloración, que ocurren en minutos o segundos, se observan en L. salvadorensis García-Ríos, 2006 (Pacífico oriental tropical), L. liozonis (en Puerto Rico) y también se observa en L. pseudoliozonis. Los ejemplares preservados en alcohol se tornan más claros.

La otra diferencia entre L. liozonis y $L$. pseudoliozonis es el largo de sus espículas marginales. Kaas (1972) examinando el holotipo de L. liozonis, describe las espículas marginales como cortas, $50 \mu \mathrm{m}$ de longitud, ampliando gradualmente hacia el ápice ("club-shaped”), distalmente acanaladas. Posteriormente, en la redescripción de la especie, ofrecen un rango de 40 a $50 \mu \mathrm{m}$ de largo para esas espículas marginales (Kaas, \& Van Belle, 1985). La descripción y el tamaño concuerdan con la foto del microscopio electrónico de barrido de esas espículas para ejemplares de Puerto Rico (García-Ríos, 2003). Las espículas marginales de L. pseudoliozonis miden $100 \mu \mathrm{m}$ de largo, el paratipo CBUPRH \#2467 muestra espículas marginales de $120 \mu \mathrm{m}$ de largo.

Tanto el holotipo de L. pseudoliozonis, como siete de los paratipos muestran una fuerte concavidad en la pendiente posmucronal. Solo los dos paratipos más pequeños (CBUPRH \#2465 y \#2466) muestran esa pendiente con poca concavidad. En los ejemplares de $L$. liozonis coleccionados en Puerto Rico la pendiente posmucronal es derecha y solo excepcionalmente es algo cóncava (García-Ríos, 2003).

\section{AGRADECIMIENTOS}

Agradezco a Migdalia Álvarez Ruiz de la Universidad de Puerto Rico en Ponce y a Jonathan Sánchez, del Programa de Biología Marina Costanera de la Universidad de Puerto Rico en Humacao (UPR-H), el apoyo en las recolectas. El segundo viaje de recolecta fue auspiciado por el Programa MBRS-RISE de la UPR-Humacao (R25 GMO75348-09). El microscopio electrónico de barrido fue prestado por el Programa Partnership for Research \& Education in Materials (PREM) de la Universidad de Puerto Rico-Humacao (NSF-DMR-0934195). El trabajo bioquímico contó con la asesoría de Francisco A. Fuentes y Rosalmari de Jesús Delgado, ambos del 
Laboratorio de Biotecnología de la UPR-Humacao. La secuenciación se realizó en el Centro de Secuenciación y Caracterización Genética de la UPR-Río Piedras, ésta es apoyada en parte por las siguientes agencias: NCRR-AABRE Grant \#P20 RR16470, NIH-SCORE Grant \#S06 GM08102, Departamento de Biología de la UPR, NSF-CREST Grant \#0206200 y NINDSSNRP U54 NS39405. Jeroen Goud, curador del Museo Nacional de Historia Natural (Naturalis), Leiden, Holanda, facilitó fotografías de los tipos de Lepidochitona liozonis var tropica. Agradezco las críticas y correcciones al manuscrito de Edgardo A. R. Ortiz Corps. El Fondo para la Investigación de la UPR-Humacao me permitió completar este manuscrito.

\section{RESUMEN}

El género Lepidochitona (Gray, 1821) agrupa a quitones relativamente pequeños con un cinturón distintivo, por estar cubierto dorsalmente por corpúsculos calcáreos no solapados. Esta representado en el Caribe por cuatro especies: L. liozonis (Dall, \& Simpson, 1901), L. rosea Kaas, 1972, L. rufoi García-Ríos, 2010 y L. bullocki García-Ríos, 2011. La inspección de una muestra de ejemplares de los cayos de la Florida permite distinguir ejemplares de lepidoquitones que podrían clasificarse como L. liozonis (la única especie del género informada para la Florida) por no presentar grandes diferencias morfológicas que justifiquen su separación de los de Puerto Rico (localidad del tipo). Sin embargo, la comparación de secuencias del gen mitocondrial que codifica para el citocromo oxidasa I (COI) de los ejemplares de la Florida con ejemplares de L. liozonis de Puerto Rico evidencia una divergencia de 14\%. Esta divergencia es incompatible con especies reproductivamente conectadas. Además de sus diferencias genéticas, la nueva especie se puede distinguir de su especie gemela por ser de mayor tamaño, tener espículas marginales más largas y una pendiente posmucronal muy cóncava.

Palabras clave: Mollusca, Polyplacophora, Ischnochitonidae, Lepidochitona, Caribe, especie hermana.

\section{REFERENCIAS}

International Code of Zoological Nomenclature. (1999). International code of zoological nomenclature (4th ed.). London: ICZN.

Folmer, O., Black, M., Hoeh, W., Lutz, R., \& Vrijenhoek R. (1994). DNA primers for amplification of mitochondrial cytochrome c oxidase subunit I from diverse metazoan invertebrates. Molecular Marine Biology and Biotechnology, 3, 294-299.

García Ríos, C. (2003). Los quitones de Puerto Rico. San Juan, P.R.: Isla Negra.

García-Ríos, C. I. (2006). A New species of Lepidochitona (Mollusca: Polyplacophora) from El Salvador. Veliger, 48, 206-214.

García-Ríos, C. I., Pérez-Pérez, N. M., Fernández-López, J., \& Fuentes, F. A. (2014). Calibrating the chitons (Mollusca: Polyplacophora) molecular clock with the mitochondrial DNA cytochrome C oxidase I gene. Revista de Biología Marina y Oceanografía, 49, 193207. Recuperado de http://www.redalyc.org/articulo. oa? id=47931776003> ISSN 0717-3326

Hall, T. A. (1999). BioEdit: a user-friendly biological sequence alignment editor and analysis program for Windows 95/98/NT. Nucleic Acids Symposium Series, 41, 95-98.

Kaas, P. (1972). Polyplacophora of the Caribbean Region. The Hague: Martinus Nijhoff.

Kaas, P., \& Belle, R. (1985). Monograph of living Chitons: (Mollusca: Polyplacophora) [Monograph]. doi: ISBN-10: 9789004074149.

Kaas, P., \& Belle, R. (1998). Catalogue of living chitons (Mollusca, Polyplacophora. Leiden, the Netherlands: Backhuys.

Kelly, R. P., Sarkar, I. N., Eernisse, D. J., \& Desalle, R. (2007). DNA bar-coding using chitons (genus Mopalia). Molecular Ecology Notes, 7, 177-183.

Knowlton, N. (2000). Molecular genetic analyses of species boundaries in the sea. Hydrobiologia, 420, 73-90.

Littler, D., \& Littler, M. (2000). Caribbean reef plants. Washington, D.C.: OffShore Graphics.

Pilsbry, H. A. (1940). Nautilus 53(3), pl 12, f 4.

Redfern, C. (2013). Bahamian seashells: 1161 species from Abaco, Bahamas. Boca Raton, Florida: Bahamian Seashells.

Saitou, N., \& Nei, M. (1987). The neighbor-joining method: A new method for reconstructing phylogenetic trees. Molecular Biology and Evolution, 4, 406-425.

Tamura, K., Dudley, J., Nei, M., \& Kumar, S. (2007). MEGA4: molecular evolutionary genetics analysis (MEGA) software version 4.0. Molecular Biology and Evolution, 24, 1596-1599.

Thompson, J. G., Higgins, D. G., \& Gibson, T. J. (1994). CLUSTAL W: improving the sensitivity of progressive multiple sequence alignment through sequence weighting, position-specific gap penalties and weight matrix choice. Nucleic Acids Research, 22, 4473-4680.

Ward, R. D. (2009). DNA barcode divergence among species and genera of birds and fishes. Molecular Ecology Resources, 9, 1077-1085. 